\title{
The Contributions of the Scholars for Understanding and Indexing of the Qur'anic Subjects in Arabic and Urdu Languages - Critical Analysis
}

\author{
Aziz-ur-Rehman Saifee ${ }^{1}$, Muhammad Ishaq,", Ubaid Ahmed Khan ${ }^{2}$ \\ ${ }^{1}$ Department of Arabic, University of Karachi, Pakistan \\ ${ }^{2}$ Department of Usool-ud-din, University of Karachi, Pakistan
}

Copyright $\bigcirc 2019$ by authors, all rights reserved. Authors agree that this article remains permanently open access under the terms of the Creative Commons Attribution License 4.0 International License

\begin{abstract}
Allah revealed that the complete code of life for all mankind is to seek guidance as mentioned "The month of Ramadan is that in which was revealed the Qur'an a guidance for the people and clear proofs of guidance and criterion." (1) It is further stated: "Guidance to those who are Al-Muttaqeen (2) [the pious and religious persons who fear Allah much (abstain from all kinds of sins and evil deeds which He has forbidden). Furthermore, the following verses "[This is] a blessed Book which we have revealed to you, [O Muhammad], that they might reflect upon its verses and that those of understanding would be reminded." And "Then do they not reflect upon the Qur'an? Or are there locks upon [their] hearts?", also remind us to understand, and act upon by reflecting upon its verses to seek guidance. The scholars have been trying to facilitate the understanding of the Qur'an since its revelation took place and preserved. This study tries to explore the efforts of scholars who have collected the meaning of Qur'anic-words, which is the first step towards understanding of the Qur'an. In short, this collection is not only focusing on and analyzing the contributions of the scholars regarding LUGHAT-UL-QUR'AN, MAJAZ-UL-QUR'AN and GHARIB-UL-QUR'AN, but also gathered the contribution of scholars regarding indexing of the QUR'AN.
\end{abstract}

Keywords Lughat-ul-Qur'an, Ghareeb-ul-Qur'an, Majaz-ul-Qur'an, Meaning of Qur'an, Guidance Book, Indexing of Qur'an

\section{Introduction}

Allah, to all of us, for the guidance and for the success in this world and the world after, has given in the form of the Holy Qur'an, a complete code of life, which is in itself is a source and fountain of guidance, it is made clear guidance for mankind. (3) The pious make much use of this fountain head of benefits and guidance. (4) It is in a meant for guidance and "guidance for the pious". (5) Further, the verse of the Qur'an reads "This is a blessed Book, We have revealed to you, so that the deliberate in its verses and so that the men of understanding may head to advice." It means that it is a sacred and blessed book which Allah has revealed to us, so that people should ponder on these verses and the people of understanding should get an advice, Further, the Qur'anic verses read, (6) "Will they not then, ponder over the Qur'an, or is it that on the hearts are their locks? There are innumerable uses of the Qur'an, like these mentioned above which provoke to understand the Qur'anic verses, to ponder on them, the subject matters Qur'anic orders to get advice are very clear. Keeping the needs and requirements, for the length of the benefits masses, the Qur'anic scholars have render precious services to make the Qur'an easily understood all its knowledge and awareness in every time and in every period. They are available in so many Libraries and book houses, so that people can make use of them according to their affordability.

To understand the Qur'an, the most basic thing is to understand the Qur'anic words and lexical items. This is the first step towards understanding the Qur'an. The grammar, rhetoric, literary knowledge and all other knowledge are of the secondary importance. (7)

\section{The Books Written in Arabic Language on the Word Meaning of the Qur'an}

There are so many books in Arabic language to understand the meaning of the Qur'anic words. The great scholars of language like Zajaj, Farra, Akhfash, Ab 
Ubaidah, Ibne Qutaibah, Abu Amru Zahid, Ibne Duraid, Abu Bakar Ibne al-Anbari, Azizi, Raghib Isphani and Abu Haiyan Undlusi etc. have written memorable books. But all of these books are written in Arabic language. And now they are not available. Molana Abdur Rasheed in the preface of his book, Lughat al Qur'an has written that among all these books only sayings of Imam Raghib is available. Allama Jalaluddin Sayuti calls this book, in the series, the best book. It in real the matchless book in regard of research and use of lexicography of Qur'an. (8)

Besides, Haji Khalifa in Kashfuzonoon, in reference to Iilm Ghreeb al-Qur'an, says while discussing Ibne al-Asir's Al-Nihaya, which is the series of the first book, is supposedly written by $\mathrm{Abu}$ Ubaidah Ma'mar bin Musannah al-Basri who died in $210 \mathrm{AH}$. He had written a small book in this Science. The book was small in volume because everyone who takes an entry into every science writes a letter and others who come after make it voluminous. Another reason of it was that in those days' ignorance and illiteracy was not that common, so, he wrote short book to give knowledge and awareness to the people. Haji Khalifa writes that he has another book on Gharib Al-Qur'an. (9)

The most ancient writer, among the writers who wrote books on the meaning of Qur'anic words is Aban Bin Taghlab bin Rabah Abu Saeed al-Bakri death: $141 \mathrm{AH}$. After him, Mawaraj bin Omer al-Sadoosi Al Basri died in 174 AH Abu Mursad bin Haris bin Soor died in 195 AH, Al Qainabi and Nazer bin Shumail al-Basri died in $203 \mathrm{AH}$, Abu Al-Hasan Saeed bin Saada al-atfash al-aswat died in 221 AH, Abu Ubaid Qasim bin Salam al Hariri Al-Koofi died in $224 \mathrm{AH}$, Abu Bakr Muhammad Ibne Al Hasan who was famous with the name of ibne Duraid al-lughawi died in $321 \mathrm{AH}$, (He did not complete his book), Muhammad bin Aziz al-Sajistani died in $303 \mathrm{AH}$, Abu Ahmed bin Kamil died in $350 \mathrm{AH}$, Abu Abdullah Muhammad bin Yousuf al Kafri Tabi died in $503 \mathrm{AH}$, Abu Muhammad Abdur Rehman bin Muhammad Abdul al-Mun'im al-Khizrji died in $564 \mathrm{AH}$, Allauddin Ali bin Usman Al-Turkamani Al Maardeni al Hanafi died in $750 \mathrm{AH}$, (the name of his book "Bahjat ul Areeb lima fi Al-Kitab al-Aziz minal Gharib.") Abdul Rehman bin al Hasin Al-Iraqi died in $806 \mathrm{AH}$, And Abu Umro Muhammad bin Abi Bakr bin Abdul Qadir al-Razi (writer of "Mukhtar Al Sihah" wrote in $668 \mathrm{AH}$, Are the followers. There is a book of Ibn al-Jaozi named "Al-Areeb Bema fil Qur'an Minal Gharib."(10)

Allama Sayooti writes that in this kind lot many books have been written by numberless people permanently. Some of them are famous. Like, Abu Ubaida, Abu Umer al-Zahid and Ibne Duraid etc. In is this kind of books, book by al-Azizi is very popular because with the help of his mentor Shaikh Abu Bakr bin al-Anbari he wrote it after continuous efforts of fifteen years. The best book which became much famous in this art is the book of Raghib Asfahani Mufardat ul Qur'an. Abu Hayyan has also written a short book of one part. (11) Haji Khalifa says that the best book in this regard is the "Mufradatul Qur'an" written by Ibne al-Sameen Ahmed bin Ali Baghdadi Halbi, died in 596 AH. (12)

Similarly, the list of the writers who wrote commentaries on the Qur'an is seen the volume third of it lying in center of Al-Dirsa tul Qur'an, Madinah Munawwara, shows the "Ma Aghlaqa min Gharib il Qur'an" by Al-Balkhi Ahmed bin Sahal Abu Zaid al-Jahiz Al-Sani (235 to 324). (13) Another book is also there by the name of "Mufradat ul Qur'an" by Al Wazaan Muhammad bin Ali bin Muzaffar Muhiuddin al Hanfi died in 410 AH. It has also mention in Kashaful Zunoon. (14)

Here it will be better to present the introduction and the difference in between Abu Ubaida Muammer bin Musnna and his commentary "Majaz ul Qur'an" and the book of Exegesis in Sahih of Imam Bukhari to the reader with the short spam of our write up. In this regard the best discussion is founded in the introduction of Book of Exegesis in Kashf ul Bari by Molana Saleemullah Khan.

\section{Abu Ubaida Muammer Bin al-Musnna and His Exegis "Majazul Qur'an"}

Abu Ubaida was born on the night when Hasan Basri died in $110 \mathrm{AH}$.(15) It means that when the night a great person and pride of knowledge and had piety departed this world, on the same night there came the birth of the arrival of another great person in the field of science of lexicography. DEPARTURE and ARRIVAL are the real eternal reality of this moral world which always remains beyond the sight of human being. The book of Lineage the pedigree of $\mathrm{Abu}$ Ubaida is mentioned in this way: Muammer bin al-Musnna, Abu Ubaida al-Taimi al-Basri al-Nahwi, Mola Bani Taim bin Murrah. (16)

Abu Ubaidah's elders Hasham bin Urwah, Raooba bin al-A'ajaj Abu Abi Umer bin Aaalah are included. Ali bin al Madini, Abu Abi Qasim bin Salam Umar bin shabah have made him reference. (17) Abu Ubaidah is the first and the Abu Ubaida Qasim is after him. (Abu Ubaidah Qasim was born in 150 or $154 \mathrm{AH}$, (18) Where as Abu Ubaidah Ma'mar was born in $110 \mathrm{AH}$ ). In the speech Faiz-ul-Bari of Allama Kashmiri has made Abu Ubaida Qasim first which is incorrect. (19) There are some mistakes in Faiz-ul-Bari which the editor of it Molana Badar Alam Mirthi wanted to correct but he was departed before doing so. Mulana Manzoor Nomani writes: "The writer personally knew that Molana Badar Alam himself had realize that there were some mistakes and during his stay in Madina he started the work of correction and revision. But a little work of that nature was done when he departed this world for the world here after. (20)

There is no doubt in knowledge of Abu Ubaida Mamar Musnna but in the science of Tradition of the Prophet he 
does not hold any high status. Allama Zahabi has mentioned him and writes: Abu Ubaida was not the man of the Traditions of the Prophet. I have mentioned him because he had vast knowledge of language and history of the people. (21)

Abu Al-Abbas Mubarad says: Abu Ubaida had the belief of the khawarij. (22) Abu says: Abu Abida was very kind to me because he took me as a Kharji of Sajistan. (23) Ali Ibne Madini use to his narrations as correct. (24) Ibne Hibban has included his name in Kitab ul Saqat. (25) Hafiz Ibne Hajar says in Taqreeb: he is not strong in analysis arguments, but everyone agrees on his experience, knowledge, and skills of lexicography. (26) Allama Dhahabi has written at the end of his biography his skill in the Arabic language was absolute but it was strange that due to confidence on him he some time used to read the Qur'an and verses incorrectly and use to say that grammar was limited. (27) He did not have any love for the Arabs. Someone asked him that he tried to go deep into everyone's pedigree, who was your own father? He said that my father told that his father was a Jew of Bajarwan. (28)

Abu Ubaida and Imam Asma'i both are contemporary scholars, and there has been contemporary rivalry in between the two. (29) Abu Ubaida was so rigid in his temperament that most of his contemporaries remained angry with him. None of his contemporary attends his funeral when died. (30) His date of death is differently mentioned, 209 to $213 \mathrm{AH},(31)$ and his books, return, goes to about two hundred. (32) Ibne Nadeem has given the number of 105 in the list. (33)

\section{The Book Written in Urdu Language on the Meaning of the Words of Qur'an}

The above discussion gives the idea that even Arabs were dependent on that sort of books to know the meaning of the unique and strange words and they wrote books in this regard.

\subsection{Lughat-ul-Qur'an}

So the non-Arabs would have more in need to know the meanings of the words, because our language is not Arabic. Keeping this in mind that this kind of words started to be undertaken in Urdu language on the subject, Allama Muhammad Abdur Rasheed Nomani writes: There are many books in our language on lexicography of Qur'an which are commonly available. But there was still a need that such a book on the subject should be written in the light of research with authenticity comprehension and be complete in itself. It should help out to understand and solve the issue of the meaning of the Qur'an in every respect. It was the finding that the Urdu language had no one of that kind book of knowledge with research. Dictionary of Qur'an has been written with the purpose. (34)

Hafiz Syed Fazal-ur-Rahman writes in preface of his book "Moajum-ul-Qur'an" about Nomani's "Lughat-ul-Qur'an": For the total science of Qur'an, exegesis, translation and dictionary scholar, according to their thinking and capacity have been working in every time and era from the beginning of Islam till today and prepared numberless volumes. Moreover, Molana Muhammad Abdur Rasheed Nomani probably in 1945 had written dictionary of Qur'an Lughat-ul-Qur'an, in six volumes (containing about more than two thousand pages). It was published by Nadwat-ul-Musanifeen Delhi and received homage and attribution. The writer had used the way of that time currently used with reference of "Para" and "Ruko" but now it is time of easiness so only reference of Surah and Verse numbers is sufficient now. So “Mu'jam-ul-Qur'an" practiced this style. (35)

\section{2. "Mu'jam-ul-Qur'an"}

Moreover, Hafiz Syed Fazal-ur-Rahman had also written about his book that the motivation, in real, of this book "Kalimat-ul-Qur'an Tafseer-o-Bayan", by Hasnain Muhammad Makhloof, published at Cairo in 1956. Molana Syed Tayyab Husain Munglori had given this book and wished to have its translation in Urdu language which would help the masses to understand the Qur'an. So, he took that book and collected other books on the subject. He brought the book "Mu'jam-ul-Qur'an" in the public after addition and deletion process in the work. (36)

\subsection{Characteristics of Mu'jam-ul-Qur'an}

1. In some books, dictionary of Qur'an compiled with the order of the base of the words for example the writer of Al-Mu'jam-ul-Mufahris has done. Since it not easy for the people to find out the base words so due to this keeping in view that all Qur'anic words are edited in their own form all alphabetically, instead of the base words.

2. All Qur'anic words are tried to be written in their Qur'anic script.

3. All chapters are made according to alphabetically order, and all sub-chapters are also made alphabetically. On the left side of every page of the whole book a bouquet are made and the word use in the chapter is given to give the view of chapter.

4. (a) Three words compound are shown as a single word of the chapters with their words in brackets, like

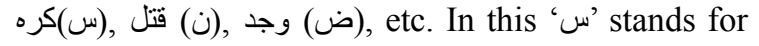

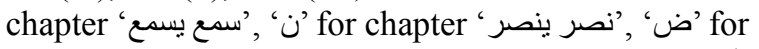

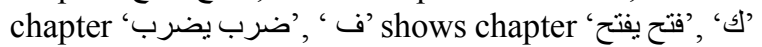

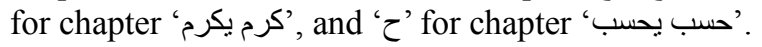
(b) Similarly for more than three words compound are shown in attached brackets, the beginning two or 


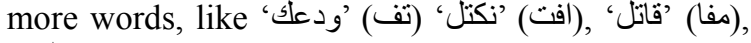
'نلقي) '(اف), etc

(c) Where ever, there occurs many demotion one part of one chapter, the chapter is made with first word of the three word compound and more like نسئل) (ف) "نسئلك، نسئلنهم، نسئلن. All these derivate are from one chapter (ف), so the first word with bracket (ف) is shown to indicate the chapter. Moreover same done with نذيقن، نذيقهم، نذيقه، نذيقهم, all these three folded derivation are from the chapter (ف).

The list of word in such a way that the last latter that has come with its accents signs (zair, zabar, paish, etc) with difference at many places, it is mentioned with its last letter is accent that is, zair, zabar, paish and tanween etc, with reference separately for example: ‘بلد، بلدا،'Balada', 'Baladun', 'Balady', 'Balad', 'Bald', 'Balado'.

5. Usually those meanings of the words are given which are, in views of the scholars and exegesis, think what is meant by the Qur'an. In this regard, the books of Shah Rafi Uddin, Molana Ashraf Ali Thanvi, Imam Raghib Asfahani's book 'Al-Mufradat fi Ghareeb-il-Qur'an and Molana Muhammad Abdur Rasheed Nomani's Lughat-ul-Qur'an are worth mentioning. Moreover, those words which are used in different meanings at different places in the Qur'an are mentioned with translation and references separately again.

6. The grammar of the words along with the meanings is given in a very simple language. Base words of all duration are mentioned. If a word is a noun, in case of being singular it's plural, and in case of plural its singular are given, indicating their masculine and feminine form. Those words which are used both as noun and base verb, both positions are ideated respectively. All the explanation is given with every exercise. The first word is used to give the details of this kind in one part in one chapter more than one derivations and forms and themes.

7. After giving meaning of every word and the explanation of its grammar the reference or references of the word is given. Those words which have occurred in the Qur'an more than 10 times or places, their references are left to avoid unnecessary details. However, these kinds of words are most often given their two to three references. In past, it was a custom to given Juz', and Ruku for reference of words, which used to pose some difficulties searching them. Now, for the easiness references are made to surah and verses numbers. Same method is applied in the book in review. The number on the line on the word shows the verse number in which the word used, and the number under neath the line indicated the chapter/ surah number.

In some scripts of the Qur'an numbers are not mentioned properly or having over ness so, it is requested to see the number up and down in case it is difficult to find the exact number.

8. In the first edition prepositions was not narrated but now it has been given with the meanings in brackets, like أتو they come (without preposition) they brought، تاب he refrained with preposition he repented, he accepted repentance, ترغبون you are allured, with preposition في you want, with preposition عن عن you avoided, you ignore etc.

9. In the Qur'an there are many words with additions, like بأمو المو ال سيدخلون original word isinal word is etc. these sort of compound of words where included the first edition, and in this revised edition more such words are included in this way many words are repeated But it is done for the facility of masses.

10. In the first edition, explanation notes, due to their importance were given with some words, in second edition more such notes are included.

11. Words are taken separately with their last letter accents.

\subsection{Subject Wise Indexing of the Qur'an}

These books were written on the meanings and alphabet of the Qur'an although all these books are unique in their own, yet it was difficult for a common reader to make use of them. Moreover, in these days there were many Huffaz of Qur'an who had learnt the Qur'an by heart and they had particular interest in the meanings and subjects of the Qur'an so they did not face any particular difficulty in finding the words of the verse and different kind of subjects in the Qur'an. But later on where people become sluggish and they lacked interest in the Qur'an they faced difficulty in the finding the verses and the subject in the Qur'an. Some of the scholars felt the need to edit the subject's index of the Qur'an, so that Qur'anic verses and subject should be found easily and immediately, and particularly different verses on one subject should be found. It should be useful to the research scholars and students and scholars and writer should also be benefited equally.

\subsection{Nujoom-ul-Furqan Fi Atraaf-II-Qur'an}

In this regard the most important book is book of Flojal orientalist al Mani's book of Nujoom-ul-Furqan fe Atraf-il-Qur'an Dr. Mansoor Fahmi in the preface and importance of Qur'an in a vast community. They realize that eastern Muslims and western people meet with each other for different purpose. For this he started working on different indexes to make easy finding of Qur'anic verses and subjects. So, Flojal Al-Mani wrote the book Nafoom-ul-Furqan fi Atraaf-il-Qur'an. Besides, in the present time Muslims writers also wrote book on the subject like Miftah Kanooz-ul-Qur'an, Kitab Fatah-ur-Rehman, Kitab Tarteeb Zeba etc. (37) 


\subsection{Al-Mu'jam-ul-Mufharis Li Alfaz il Qur'an Al-Kareem}

It is very good that the Muslim writers and researchers paid heed to this direction, and particularly Muhammad Fawad Al-Baqi wrote Muajum Mufharas lil Alfaz Al-Kareem and it was published in 1939. Muhammad Fawad Al-Baqi writes about his books that though in this art, without any objection and reservation the best writing and the most comprehensive book is Nojum-ul-Furq'an fi Atraaf-il-Qur'an. This is the writing of the Mustarshiq Flojal Al-Mani. I have made this book as a base and foundation for my Muajum. (38)

Muhammmad Fawad al Abdul Baqi has mentioned all those errors committed by Flojal. He has edited Mu'ajum after the corrections. Those sort of errors are probably picked up by even great scholars because if having no deep knowledge of grammar and lexica/sciences.

\subsection{Lughat-ul-Qur'an (Al-Yaqoot wal-Marjan)}

It is a popular book of Sheikh Muhammad Hammadullah Sindhi died in $1381 \mathrm{AH}$, written in Arabic language and on this art. The preface of the book is written by Allama Muhammad Yousuf Banori and it is published by Majlis-ul-Taawun Al-Islam Karachi. Hazrat Benori has written about the characteristics:

"He has written books on the solution of the dictionary of the Qur'an in order of Mu'ajum. He did not confine only to take extracts from Mufradat-ul-Qur'an by Imam Raghib but also referred the other present day books like Kitab-ul-Lughat, dictionary, commentaries, explanation, Muntaha al-Arab, for example Kashaf of Allama Zamakhshari, exegesis of Imam Razi Tafseer e kabir and Ibne Kaseer exegesis. He has collected important and high standard knowledge from all of them. This does not suffice, but he has included delicate discussion, etymology, lexicography and Arabic literature. The book of him is not only simple dictionary but also complete index as well. It tells the number of the verses and ruku with the words, so it is made known in what part this word is used. In this way the reader not only comes to know the verse of every word and its Ruko, place, but its meaning explanation, grammar, research and the difference in the meaning, if there is any. It was very much surprising that Allah has taken such a big task from a person who had been brought up in these cities, got education in these missionary traditional Institutes and accompanied with such people who did not have any particular interest and inclination towards Arabic literature, and nor he had himself such interest and inclination towards literary books. (39)

\subsection{Al-Fehris-ul-Ma'udhuee for Verse of Qur'an-ul-Kareem}

At the same level and standard we find a book named Kitab-ul-Fehris al Maudhuee le Ayat il Qur'an il Kareem by Muhammad Mustufa Muhammad. Dr. Ahmed Abdus Sattar Al-Jawari writes: The people who have been given guidance of the right path one of them is Muhammad Mustufa Muhammad, who has been selected for the service of His Book. He selected the Qur'anic words separately on the basis of subjects, thoughts and orders. May Allah keep his beneficent ongoing and make it useful for the people". (40)

The writer Muhammad Mustufa muhammad writes about his own book: "New change has occurred in the education not only of Qur'an and Islamic studies rather too many services are included in education. It is obligatory now on a student that he must learn many services and skills. This situation has emphasized the need that the index of Qur'an is to be made subject-wise, though commentators have already worked on it. Yet there was a need that the Muslim researchers should undertake the task. If sometimes there is no one who has learned the Qur'an by heart, or due to any reason, the verse does come into memory or some particular subject, one can get all the verses at one place on the subject. (41)

\subsection{Manshoor Qur'an}

The constitution of Qur'an, Manshoor Qur'an by Abdul Hakeem Malik, which is in three languages Urdu, Arabic and English, is a very comprehensive index of the subjects of the Qur'an. It is of a great importance and it is an outcome of his 18 years' labor and efforts. In the preface he himself writes: "In 1975, during the education of law, I had developed the interest to prepare a reference book of Qur'anic subjects. That should give the chapters and the verses of the Qur'anic subjects, separately at one place to get guidance on every day issues. The present time research has made the solutions of most of the issues of life due to research of human brain, like the law journals on bare acts of civil and criminal codes and court verdicts, ready reckoners on technical fields, medical sciences. Encyclopedias are also available now a day in respect of every occasion at a glance. So he started this work in the environment of the Kaaba, Saudi Arabia, in 1978. He started noting down, under separate subjects, from the authentic translations of the Qur'an. In this way a research work in five volumes was prepared. In real, no research work is as easy as it is thought before doing that. When a human being takes a start of the work, he comes to know its depth and width. It is not possible to have comprehensive exhaustive index of the Qur'an on its meaning and awareness. It is the Word of Allah. Its every verse / ayat has so much depth in different aspects of guidance and recognition treasures. It is beyond any human capacity to encompass in all. The Qur'an is a fathomless ocean and every reading and study reveals new thing on thinking and pond ration. (42)

He quotes a saying of Hazrat Ali: The Qur'an does not get old with more and more use of it. It means that as much 
it is used that much new things come up with thinking and penetration. It is wonderers that never end up. (43)

Dr. Muhammad Mian Siddiqui in the preface of The Constitution of Qur'an has written about the importance of indices and collection of lists: This book, the Qur'an, of guidance and fountainhead of guidance has a longstanding tradition that started from the ancient time to make it understandable for a common reader, and to those who do not know Arabic by giving its meanings, knowledge, explanation and commentary. This practice has been going on up till now. The scholars wrote books on the explanation of concise and uncommon verses in the name of difficulties of the Qur'an and they work on the terse and subtle language of the Qur'an. Some scholars and exegesis's worked on the orders of its chapters and verses and their interconnecting cohesiveness. Dictionaries were prepared on permanent basis as dictionaries of the Qur'an. Detailed and voluminous exegesis came upon the verses having the injunction. Some scholars made the subject of the Qur'anic stories examples and the wonders of their research. When the scientific era started the proofs of the inventions and creations were presentenced through the Qur'an.

Along with, rather a step ahead, all these efforts the scholars paid their attention on the meanings, objectives, list of the Qur'anic subjects and indices. This work is not of lesser importance. This made it an easy approach of the people towards the Qur'an who do not have a command on the language. This also made easy for those people who want to devote their efforts toward a subject due to their business, out of the subjects for their research and academic efforts. (44)

\subsection{Jamia Ishariah Mazameen Qur'an (Comprehensive Index of the Subjects of Qur'an)}

Another work of this kind of its more importance is done by Dr. Athar Muhammad Ashraf (late) under title: Jamia Ishariah Mazameen Qur'an. He has completed this work after the hard work for about eleven years. Although I do not have a longstanding acquaintance with him, Dr. Shabir, in the month of Ramdhan, 2013, presented his book "A Brief Index of the Qur'an" to me during my Eitkaf day in Shadab Mosque, which was published in 2005. In this way, I came in contact with him. I was very much delighted to see his work. It also evoked the idea that it would be better and easy for a common reader to reach the Qur'an if a detailed and comprehensive index is made by someone. In this way different verses on one subject can be found at one place. Lot of works in Arabic and Urdu languages have been done as already mentioned above, however, it would have been better if that sort of work has been done. Now, it is known that you have done such work, it is completed and even published and its opening ceremony is going on. A few days earlier, there came a chance to meet the doctorthe writer. He is as delicate, pure and high as his name is. $\mathrm{He}$ is the rider of the field of academic knowledge and research. Dr. Pirzada Qasim, ex-vice chancellor, university of Karachi has written: I have seen another book of him which is a collection of a part of Qur'an_the collection of the verses on "Qul". It is revealed that the "Qul" has occurred 332 times in the Qur'an. Doctor the writer has not only pointed out the 306 verses with the word "Qul" but he has given their references and contexts. In this way a very useful and better book was edited. Dr. Ather Muhammad Ashraf is a paragon of knowledge and kindness. It gives pleasure and contentment when we talk to him. His work and devotion to it, sincerely of his temperament indicate that he would keep on his Qur'anic research work and produce much more meaningful words in this field. (45)

Dr. Syed Aziz Ur Rahman has written about him: "The hard work and insight of the writer are exhibited with the volume that contains 115 or more important subjects and numerous sub-titles of them. The index, hence, comes up to 2500 pages. The list of this index runs into many pages. This shows the hard labor and vast knowledge of the writer." (46)

He himself, the writer, Dr. Athar Muahmmad Ashraf writes about the index in its preface: "When I showed, after editing, the brief index to Mufti Badar Alam, teacher of Darul Uloom, Korangi Karachi, he pointed out: If you have done so much work On the Qur'an why not to work in complete details. I started this work with the prayer of Mufti and laid the foundation of this work. I lay out the work in this way that a short synopsis was made of the subject's titles and the verses after reading them and extracting their subject matters. In the first step reference available on subjects and titles of each verses were listed down. In the second step all the references to each chapter under the subjects and title were collected together all the tittles, according to alphabetical order were arranged in the third step. All the subjects of the chapters were divided into two parts in the fourth step. In the first part a collection of 34 chapters of the Qur'an from the first chapter and after that in the second part a collection of the subject of the chapter from 35 to 114 was made. In fifth, the final step, a collection was made with the combination of the two for the Qur'anic subjects Zahid Malik was taken into consideration, for the selection of the Arabic words Mu'jam-ul-Qur'an by Syed Fazul Rehman was followed and along with them Mu'jam-ul-Mufahris by Muhammad Fawad Baqi was also used for the benefits of having more reference of more verses. (47)

No doubt, it is very difficult, hard, laborious, patient and enduring work. The habit of Dr. Ather Muhammad Ashraf of hard working has made it easy task. The writer is a good writer. The views of scholars and researchers are to be read in the beginning of the book. Everyone has appreciated him and his work is worthy of praise and appreciation. It is an obligation and fulfillment for the Ummah by the scholars. Since it is a different and hard work to connect the verses and words of the Qur'an with some particular subjects and titles so it needs intensive and extensive knowledge and 
study. The writer has been enjoying patronage of the scholars, Mufti Badar the teacher of Darul Uloom Korangi Karachi in particular who had himself gone through the script. He with reference to his earlier life, is a businessman thus passes in his everyday life in the ups and downs of business. When he was involved with construction world be himself, and no one else can believe after knowing him that it is possible that such a person who is involved in the maze of the world affairs could attach himself permanently with study of the Qur'an. He can, after not one or two years but of hard work of 10 years with the blessings of Allah, produce such a work on the Qur'anic subjects not for only his benefits but for the benefits of all from a scholar to a common person knowing only Urdu language with little education to get guidance from index of the Qur'an finding it is easy to have benefits and approach to the word of Allah. (48)

\section{Results and Recommendations}

Since Qur'an is the guidance for mankind all over the world, the Religious Scholars contributions are made and published for the understanding of Qur'an Kareem and its indexing in every era to provide them easy source to reach the references and to achieve their goals and tasks as soon as required. I tried to collect few contributions in Arabic and Urdu languages and gathered in an article but space is empty for scholars to collect the contributions of scholars in other languages as well in future.

\section{REFERENCES}

[1] Surah Baqarah: 185.

[2] Surah Baqara: 2.

[3] Surah Baqarah: 185.

[4] Surah Baqara: 2.

[5] Surah Saad: 29.

[6] Surah Muhammad: 24

[7] Preface of Silkul Eqyan linazmil al-yaqoot wal-marjan, Muhammad Yousuf Banori, Publisher: Majlis Ta'wun Islami, 2001, Page: 5.

[8] Lughatul Qur'an, Molana Abdur Rasheed Nomani, vol.: 1, Page: 3 .

[9] Al-Nihayah, Ibnul Aseer, (544 hijri - 606 hijri), Darul Marifah, Beirut, first edition, 2001, vol.: 1, Page: 33, Kashfuz Zunoon, haji Khalifa, vol.: 1, Page: 1203.

[10] Kashfuz Zunoon, haji Khalifa, vol.: 1, Page: 1207-1208.

[11] Al-Itqan fi Uloomil Qur'an, Allama Jalal Uddin Sayooti, (849 hijri-911hijri), Idara Islamiat, Lahore, 1982, vol.: 1,
Page: 306.

[12] Kashfuz Zunoon, haji Khalifa, vol.: 1, Page: 1208.

[13] Index musanafat tafseerul Qur'an, Center of Al-Dirasatul Qur'ania, Madina Munawarah, 1424 AH, Mujamma King Fahad, Vol:: 3, Page: 1135, Also see: Alfihrist, by Ibne Nadeem, Page: 37, 153, Ezahul Maknoon, Vol.: 1, Page: 303, Hadyatul Arfeen, vol.: 1, Page: 59.

[14] Index musanafat tafseerul Qur'an, Center of Al-Dirasatul Qur'ania, Madina Munawarah, 1424 AH, Mujamma King Fahad, Vol.: 3, Page: 1135, Also see: Alfihrist, by Ibne Nadeem, Page: 37, 153, Ezahul Maknoon, Vol.: 1, Page: 303, Hadyatul Arfeen, vol.: 3, Page: 1244.

[15] Seear A'lamin Nubala, Imam Zahabi, vol.: 9, Page: 445.

[16] Tahzeebul Kamal, vol.: 28, Page: 316-317, Seear A'lamin Nubala, Imam Zahabi, vol.: 9, Page: 445, Wafayatul A'yan, vol.: 5, Page: 235 .

[17] Seear A'lamin Nubala, Imam Zahabi, vol.: 9, Page: 445-446.

[18] Wafayatul A'yan, vol.: 4, Page: 62.

[19] Faiza-ul-Bari, Allama Kashmiri, Vol.:4, Page: 194.

[20] Shaikh Muhammad Abdul Wahab and Scholars of Hind, Page: 111.

[21] Seear A'lamin Nubala, Imam Zahabi, vol.: 9, Page: 445.

[22] Index of Ibne Nudaim, page: 59.

[23] Seear A'lamin Nubala, Imam Zahabi, vol.: 9, Page: 447.

[24] Tareekh Baghdad, Vol.: 130, Page: 257.

[25] Kitabus Siqat, Ibne Hibban, Vol.: 9, Page: 196.

[26] Taqreebut Tahzeeb, Page: 541, Biography No: 6812.

[27] Seear A'lamin Nubala, Imam Zahabi, vol.: 9, Page: 447.

[28] Index of Ibne Nudaim, page: 59, Wafiyatul Ayan, vol.: 5, Page: 235, Tahzeebl Kamal, vol.: 28, Page: 317, Bajerwan is village of Balakh, or village near to Sherwan, where the pond of life is found by Hazrat Khizer, or the village where Hazrat Mosa and Khizer asked for food and they refused. Mo'ajamul Buldan, Vol.: 1, Page: 313.

[29] Sharhu Muqamat by Shuraishee, Page: 2.

[30] Wafiyatul Ayan, vol.: 5, Page: 240.

[31] Wafiyatul Ayan, vol.: 5, Page: 246.

[32] Index by Ibne Nudaim, Page: 59-60.

[33] Preface of Majazul Qur'an, Page: 16-17.

[34] Lughatul Qur'an, Muhammad Abdur Rasheed Nomani, Darul Isha'at, Karachi, 1994, Page: 3.

[35] Mu'jam-ul-Qur'an, Syed Fazal-ur-Rahman, Mujaddidia Institute, Karachi, 1407 AH, Page: 8.

[36] Mu'jam-ul-Qur'an, Syed Fazal-ur-Rahman, Mujaddidia Institute, Karachi, 1407 AH, Page: 9.

[37] Preface Ma'ujam-ul-Mufahris Le Al-Faz-il-Qur'an 
Al-Kareem, Muhammad Foad Abdul Baqi, Zaw-il-Qurba Publishers, Iran, Page: 2, 1421 AH, First Edition.

[38] Preface Ma'ujam-ul-Mufahris Le Al-Faz-il-Qur'an Al-Kareem, Muhammad Foad Abdul Baqi, Zaw-il-Qurba Publishers, Iran, Page: 2, 1421 AH, First Edition.

[39] Preface Silkul Eqyan Linazmil Yaqoot walmarjan on Lughatul Qur'an, by Muhammad Yousuf Banori, Majlis Tawaun Islami, Karachi, 2001, Page: 6-7.

[40] Al-Fahris-ul-Maudhuee, Muhammad Mustafa Muhammad, Idara tul Qur'an, Karachi, 1976, Page: 7.

[41] Al-Fahris-ul-Maudhuee, Muhammad Mustafa Muhammad, Idara tul Qur'an, Karachi, 1976, Page: 9.

[42] Manshoor Qur'an, Abdul Hakeem Malick, Islamic Research Foundation, Pakistan, 2007, edition: 5, Page: 16-17.

[43] Sunan Tirmiizi, Imam Tirmizi, Hadith: 2906.

[44] Preface, Manshoor Qur'an, Abdul Hakeem Malik, Dr. Muhammad Mian Siddiqui, Page: 18.

[45] Preface, Jamia Isharia Mazameen Qur'an, Ather Muhammad Ashraf, Shaikh Zayed Islamic Center, Karachi, 2013, Page: 15 .

[46] Preface, Jamia Isharia Mazameen Qur'an, Ather Muhammad Ashraf, Shaikh Zayed Islamic Center, Karachi, 2013, Page: 16.

[47] Preface, Jamia Isharia Mazameen Qur'an, Ather Muhammad Ashraf, Shaikh Zayed Islamic Center, Karachi, 2013, Page: 16.

[48] Preface, Jamia Isharia Mazameen Qur'an, Molana Muhammad Idrees Hoshiyar Poori, Jamia Darul Uloom Rahimia, Multan. Page: 05. 